\title{
2 Samuel 17, 3.
}

\section{כשוב הכל האיש אשר אתה מבקש}

Das Ungrammatische und Unnatürliche des Satzes fällt auf; die Uebersetzungen und Erklärungen geben keinen rechten Sinn; sogar die Hülfe der LXX ist meiner Ansicht nach nicht „glänzend" (Thenius).

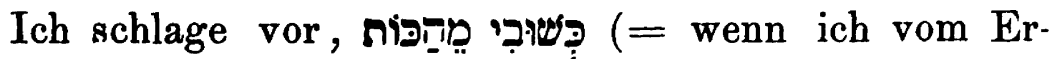
schlagen zurückgekehrt bin) zu lesen und beziehe מהכות direct auf והכית im vorhergehenden Satz.

Achithofel sagt demnach :

${ }_{n}$ Ich will mich aufmachen, David verfolgen......, und den König allein erschlagen. Ich werde dir das ganze Volk zuführen : sobald ich von meinem Ueberfall (wörtlich : vom Erschlagen des Mannes ...) auf den Mann, den du suchst, zurückgekehrt bin, wird das ganze Volk dir friedlich gesinnt sein."

Zum Schlusse bemerke ich noch, dafs die Formel שוב מהכות in Samuel häufig vorkommt. Vgl. :

1 Sam. 18, 6

2 Sam. 1, 1

Budapest.

8,13 .

Prof. Salomon Schill. 